\title{
The effect of age at first marriage on the incidence of labor complications and babies with low birth weight in Indonesia
}

\author{
Fajar Maulinda ${ }^{1}$, Dwini Handayani ${ }^{2}$, Turro S. Wongkaren ${ }^{3}$ \\ ${ }^{1}$ Staff, Statistics of Riau Province, Riau; ${ }^{2}$ Assistant Professor, Faculty of Economics and Business, Universitas Indonesia, Depok; ${ }^{3}$ Director, Lembaga Demografi, \\ Faculty of Economics and Business, Universitas Indonesia, Depok, Indonesia
}

Purpose: This study investigated the effect of a woman's age at first marriage (AFM) on the incidence of labor complications and babies with low birth weight (LBW). Methods: This study used data from the 2017 Indonesian Demographic and Health Survey (IDHS) on women aged 15-49 years who gave birth to their first child within the previous 5 years. Data analysis was conducted using binary logistic regression for labor complications and the binomial probit method for the incidence of LBW. Results: The analysis showed that AFM affected the likelihood of childbirth complications and LBW babies. An increase in AFM tended to reduce the risk of childbirth complications, although poor economic conditions increased the risk of complications in mothers with a higher AFM. In addition, a low or high AFM increased the chances of delivering a baby with LBW. Conclusion: A low AFM was associated with an increased likelihood of women experiencing birth complications when delivering their first child and delivering babies with LBW, underscoring the importance of delaying childbirth until a more mature age.

Key words: Labor complications; Low birth weight; Marriage

\section{Corresponding author Fajar Maulinda}

Statistics of Riau Province, Pattimura street no.12 Pekanbaru Municipality,

Riau 28131, Indonesia

TEL: +62-761-23042

FAX: +62-761-21336

E-MAIL: fmauli@bps.go.id

This article was adapted from a thesis by Fajar Maulinda in partial fulfillment of the requirements for the master's degree at Universitas Indonesia.

\section{Received Dec 26, 2020 \\ Revised Feb 1, 2021 \\ Accepted Mar 21, 2021}

This is an Open Access article distributed under the terms of the Creative Commons Attribution NonCommercial License (http://creativecommons.org/licenses/by-nc/4.0/) which permits unrestricted noncommercial use, distribution, and reproduction in any medium, provided the original work is properly cited.

\section{INTRODUCTION}

A young woman's body is still developing and is not necessarily ready to carry babies. Adolescence is a time during which the body's physiological development continues, requiring sufficient nutritional intake to produce energy for growth However, a pregnant adolescent's nutritional intake is shared with the fetus, resulting in insufficient nutrition for both the mother and baby, which negatively impacts their health [1].

The World Health Organization reported that around 295,000 women died during pregnancy and childbirth in 2017, with most of the deaths occurring in poor and developing countries [2]. Indonesia targeted reducing maternal mortality to 306 maternal deaths per 100,000 live births by 2019, and the 2015 Inter-Census Population Survey showed that this target had been reached, with 305 maternal deaths per 100,000 live births [3]. However, tremendous efforts must still be made to achieve the Sustainable Development Goals (SDGs) target of 70 maternal deaths per 100,000 live births by 2030 [4]. McCarthy and Maine [5] stated that childbirth complications can result in severe illness for the mother and can be a direct cause of maternal death. Moreover, the likelihood of maternity-related death is linked to the risk of obstetric complications and death during pregnancy, during childbirth, or within 42 days postpartum [6]. The 2017 Indonesian Demographic and Health Survey (IDHS) showed that the percentage of mothers who experienced labor complications in Indonesia increased from $25.9 \%$ in 1997 to $74.1 \%$ in 2017 [7].

In addition, babies with low birth weight (LBW) are highly susceptible to neonatal mortality [8]. Indonesia's 2016 neonatal mortality rate (NMR) was worse than other countries in the Association of Southeast Asian Nations with higher gross domestic products (GDP) per capita, including Singapore, Thailand, Brunei Darussalam, and Malaysia. However, Indonesia's NMR is also worse than those of Vietnam and the Phili- 
ppines, which have lower GDPs per capita than Indonesia [9]. Furthermore, LBW infants tend to have a higher risk of malnutrition (stunting, wasting, and underweight) during infancy [10]. The proportion of stunted children under 5 years old in Indonesia in 2018 was $30.8 \%$, in line with the 2019 target set by Indonesia's National Medium-Term Development Plan to reduce stunting to below $32 \%$. Indonesia's government plans to reduce the proportion of stunted children under 5 years old to $19 \%$ [11], as critical efforts to lower the percentage of LBW babies have become a central focus in maternal and child development. Additionally, LBW babies tend to have lower motor and cognitive scores than normal-weight babies as they mature [12]. When they reach adolescence/adulthood, LBW babies have a higher risk of experiencing cardiovascular diseases and obesity [13]. Thus, it is essential to further investigate the various risks to which women with labor complications and LBW babies are exposed.

In Indonesia, it is a common belief that the transformation of a girl into a woman starts when she marries. A woman's age at first marriage (AFM) might also indicate her first exposure to sexual intercourse, which can result in pregnancy. IDHS data from 1991 to 2017 show that the median AFM is on an increasing trend. However, the 2017 IDHS still shows that Indonesia has a median AFM of only 21.8 years, meaning that half of Indonesian women get married before their 21st birthday [7]. Indeed, the practice of child marriage in Indonesia remains prevalent. Poverty, poor education, cultural and religious values, and norms are among the factors behind the high rate of child marriage in Indonesia. For example, parents may encourage their daughters to marry quickly to avoid zina (adultery and premarital sex). In parts of Indonesia where child marriage is the norm, unmarried girls as young as 17 are sometimes thought of as "old virgins," and these cultural beliefs put pressure on girls to marry early [14].

In 2018, Statistics Indonesia (BPS) estimated that 1,220,900 women aged 20-24 years old had married before the age of 18 , giving Indonesia one of the top 10 highest child marriage rates in the world [15]. This poses a crucial challenge for Indonesia's development. The importance of eliminating child marriage is reflected in its inclusion as a target of the SDGs, specifically in SDG 5.3, which aims to "eliminate all harmful practices, such as child, early, and forced marriage and female genital mutilation." Reducing child marriage would help to achieve other SDGs, such as the first (no poverty), second (zero hunger), third (good health and wellbeing), fourth (inclusive and quality education), fifth (gender equality), eighth (decent work and economic growth), tenth (reduce inequalities) and sixteenth (peace, justice, and strong institutions) goals [15].

Research in developing countries has found that nine out of 10 pregnant adolescents are married, so it can be inferred that marriage at a young age also increases the chance of youth pregnancy [16]. This prevents young women from pursuing higher education and limits their access to economic opportunities, which in turn impairs their health [17]. Previous studies have shown that maternal age influences the probability of labor complications [18] and of delivering LBW babies [8,19-21]. These phenomena are also affected by other issues such as obstetrics, nutrition, antenatal care, healthcare access, economic conditions, and education level [18,20,22-25]. Yet, despite the increasing urgency to mitigate the problem, Indonesia's efforts to lower the rate of birth complications and LBW babies have progressed slowly. Thus, in light of the crucial obstacle that the age of young mothers poses to those efforts, this study aimed to understand the impact of AFM on labor complications and the birth of LBW babies.

\section{METHODS}

Ethics statement: This study was a secondary analysis of existing data and did not require institutional review board approval or informed consent.

This study used the 2017 IDHS [7], a survey which is carried out every 5 years by the National Population and Family Planning Board (BKKBN), BPS, and the Ministry of Health (Kemenkes). The 2017 IDHS provides up-to-date estimates of fundamental demographic and health indicators and includes information on maternal and infant health in Indonesia using a cross-sectional survey research design and two-stage stratified sampling. The 2017 IDHS was designed to present reliable estimates at national and provincial levels, with a sample covering 1,970 census blocks in urban and rural areas with a goal of obtaining responses from 49,250 households. Surveyors expected an estimated 59,100 women aged 15-49 years to be identified from the sampled households, but only 49,627 women were successfully interviewed from the sample.

To investigate the effect of AFM on labor complications and LBW babies, this study selected women aged 15-49 years who were or had been married, and who had delivered their first child within the 5 years preceding the survey. In this study, AFM was defined as the age at which a woman married or started living together with her husband or first partner. Mothers were determined to have had labor complications if they experienced any of the following symptoms: intense and regular heartburn for more than 24 hours, excessive bleeding, high body temperature, convulsions and fainting, discharge of amniotic fluid for more than 6 hours before the child was born, restlessness/pain, and other complications. This research used a dichotomous categorical variable to determine labor complications. Respondents chose "yes" if they experienced at 
least one type of difficulty during the delivery of their first child, and "no" if they experienced no complications. A similar dichotomous variable to identify LBW infants was also used. Respondents chose "yes" if their first child's birth weight was less than 2,500 grams, and "no" if the birth weight was greater than or equal to 2,500 grams. The WHO categorizes age into four groups: infants/newborns (before 1 year of age), children/young children (1-10 years), adolescents/older children (10-19 years), and adults (20 years and over) [26]. In terms of reproductive health, the ideal and lowest-risk age to experience pregnancy and, more specifically, birth and breastfeeding is between 20 and 34 years old. The reproductive organs of women under 20 years of age are considered immature and pose a threat to the fetus [21], while pregnancies in mothers over 35 years old are considered dangerous for both the mother and baby due to the decline of reproductive function [21]. This study, therefore, categorizes AFM into 3 groups: less than 20 years old (adolescents), 20 to 34 years old, and 35 or older. The inferential analysis used the binary logistic regression method for labor complications and the binomial probit regression method for the LBW infants.

\section{RESULTS}

The 2017 IDHS interviewed 49,627 women between 15 and 49 years old, 36,926 (74\%) of whom were married. Furthermore, 15,329 respondents had delivered a baby within the 5 years preceding the survey, and the survey collected data on 17,019 births. Among infants with reported birth weight (94.1\% of the births) in the survey data, $7 \%$ had LBW. When mothers were unable to report the exact birth weight of their babies, their perception of the baby's size was collected instead. In total, $12 \%$ of infants were considered to have been born very small or smaller than average [7]. In addition, 74.1\% of women experienced labor complications.

In total, 4,732 respondents were married mothers who had delivered their first child within the 5 years preceding the survey. After the removal of missing or incomplete variables, 4,561 observations were available as units of analysis for labor complications, and 4,593 observations were available for LBW infants. In total, $8.8 \%$ of mothers' firstborn children were underweight, $23.4 \%$ of mothers experienced no complications during the delivery of their first child, and the remaining $76.6 \%$ of mothers experienced at least one complication.

To better understand the incidence of labor complications, Table 1 presents a general breakdown of survey data from women aged 15-49 years who had delivered their first child. The descriptive results showed that $76.6 \%$ of mothers experienced labor complications during the delivery of their first child. Out of the 4,561 women for whom data on labor compli- cations were analyzed, $63.5 \%$ were married from the ages of 20-34 years, while $35.1 \%$ were married during adolescence. Nearly $40 \%$ of women $(39.7 \%$ ) were high school graduates or equivalent. $37.1 \%$ had a low education level (did not go to school or only graduated from junior high school/equivalent), and only $23.2 \%$ were college graduates. The education statistics reflect the economic status of the women. In total, $42.7 \%$ of the women came from the lowest household wealth quintiles, $39.8 \%$ came from the middle quintile, and only $17.5 \%$ of women came from wealthy households. Only $15.2 \%$ of women had a history of complications during their pregnancy. In addition, $94.4 \%$ of mothers had a planned pregnancy, and $65.2 \%$ of mothers did not experience problems accessing maternal health services. The sample's general description shows that nine out of 10 women had routine antenatal care (ANC) visits, and $99.0 \%$ of mothers chose birth attendants who were qualified medical personnel. Over half (63.1\%) of mothers knew the dangers of pregnancy and birth, and where to go and what to do if signs of danger were present. In total, $94.3 \%$ of mothers had discussed the delivery preparation with others before their child's birth.

To better understand the incidence of LBW infants, Table 2 presents the sample distribution of women whose children had recorded birth weights. The descriptive results showed that only $8.8 \%$ of mothers delivered LBW babies in the delivery of their first child. Of the 4,593 women for whom data regarding their child's birth weight were analyzed, $62.9 \%$ married between the ages 20 and 34,35.7\% married in their teens, and $1.4 \%$ married at 35 or older. In total, $39.5 \%$ of the women graduated from high school or equivalent, $37.4 \%$ had no education or only graduated from primary school, and $23.1 \%$ completed tertiary education. The sample distribution also shows that $43.1 \%$ of women came from poor households, and the remaining were from middle or high income families. In total, $14.9 \%$ of mothers had a history of pregnancy complications, $94.3 \%$ planned their pregnancies, and $57.9 \%$ consumed fewer than 90 tablets of iron during pregnancy. Sixty-five percent had no problem accessing health services. Favorable findings were observed regarding health indicators, in that nine out of 10 women had four or more ANC visits during their pregnancy, and only a small fraction of the sample were smokers (1.3\%).

A previous study [27] reported that other variables also influence women's AFM, so it is necessary to examine these variables' endogeneity. Variables are considered endogenous when they are affected by other variables in a model. This problem can be overcome by using an instrumental variable for AFM. Ideally, the instrumental variable should influence the AFM, but should not directly affect labor complications and the incidence of LBW babies. This is because the in- 
Table 1. Distribution of Variables in the Analysis of Labor Complications $(N=4,561)$

\begin{tabular}{|c|c|c|c|}
\hline Variables & Categories & $\mathrm{n}(\%)$ or $\mathrm{M} \pm \mathrm{SD}$ & Min-Max \\
\hline Labor complications & $\begin{array}{l}\text { No } \\
\text { Yes }\end{array}$ & $\begin{array}{l}1,066(23.4) \\
3,495(76.6)\end{array}$ & \\
\hline AFM & $\begin{array}{l}<20 \\
20-34 \\
\geq 35\end{array}$ & $\begin{array}{c}21.7 \pm 4.5 \\
1,602(35.1) \\
2,897(63.5) \\
62(1.4)\end{array}$ & $10-42$ \\
\hline Education (year) & & $10.4 \pm 4.3$ & $0-18$ \\
\hline Level of education & $\begin{array}{l}\text { University } \\
\text { High school } \\
\text { No school or only primary }\end{array}$ & $\begin{array}{l}1,060(23.2) \\
1,809(39.7) \\
1,692(37.1)\end{array}$ & \\
\hline Economic status & $\begin{array}{l}\text { Highest }(20 \%) \\
\text { Middle }(40 \%) \\
\text { Lowest }(40 \%)\end{array}$ & $\begin{array}{r}797(17.5) \\
1,815(39.8) \\
1,949(42.7)\end{array}$ & \\
\hline $\begin{array}{l}\text { History of pregnancy } \\
\text { complications }\end{array}$ & $\begin{array}{l}\text { No } \\
\text { Yes }\end{array}$ & $\begin{array}{r}3,867(84.8) \\
694(15.2)\end{array}$ & \\
\hline Pregnancy status & $\begin{array}{l}\text { Planned } \\
\text { Mistimed } \\
\text { Unwanted }\end{array}$ & $\begin{array}{c}4,306(94.4) \\
228(5.0) \\
27(0.6)\end{array}$ & \\
\hline $\begin{array}{l}\text { Discussion about delivery } \\
\text { preparations }\end{array}$ & $\begin{array}{l}\text { No } \\
\text { Yes }\end{array}$ & $\begin{array}{c}262(5.7) \\
4,299(94.3)\end{array}$ & \\
\hline $\begin{array}{l}\text { Problems accessing health } \\
\text { services }\end{array}$ & $\begin{array}{l}\text { No } \\
\text { Yes }\end{array}$ & $\begin{array}{l}2,973(65.2) \\
1,588(34.8)\end{array}$ & \\
\hline $\begin{array}{l}\text { Knowledge of dangers and } \\
\text { complications }\end{array}$ & $\begin{array}{l}\text { No } \\
\text { Yes }\end{array}$ & $\begin{array}{l}1,685(36.9) \\
2,876(63.1)\end{array}$ & \\
\hline Frequency of ANC visits & $\begin{array}{l}\text { Routine }(\geq 4) \\
\text { Not routine }(<4)\end{array}$ & $\begin{array}{c}4,236(92.9) \\
325(7.1)\end{array}$ & \\
\hline Maternity assistant & $\begin{array}{l}\text { Medical } \\
\text { Non-medical }\end{array}$ & $\begin{array}{c}4,517(99.0) \\
44(1.0)\end{array}$ & \\
\hline
\end{tabular}

AFM, age at first marriage; ANC, antenatal care; Max, maximum; Min, minimum.

strumental variable, $\mathrm{z}$, must meet the following assumptions: 1) exogenous (i.e., co-variance $[z, \varepsilon=0]$ ) meaning that there is no correlation with the error term, and 2) correlated with endogenous variables (i.e., co-variance $[z, x \neq 0]$ ).

The instrumental variables used to estimate the AFM in this study were women's birth year and the percentage of young marriages, defined as the proportion of marriages that occurred before the woman's 20th birthday, at the provincial level. This variable partially accounts for the environmental and cultural conditions of a community, since the practice of young marriage may be considered entirely reasonable in some areas and not in others. The birth year variable reflects generational behaviors and habits among women of the same birth year. Endogeneity testing using the IV probit method indicated that the AFM variable was not endogenous, so a standard regression method for each analysis unit was neces- sary for further interpretation.

The bivariate model results indicated that a woman's AFM did not statistically affect labor complications experienced during the birth of their first child (Table 3, model 1). The results of a complete (multivariate) model with control variables showed that AFM significantly affected labor complications (Table 3, model 2). Each 1-year increase in the AFM decreased the rate of labor complications by 1.042 times $(p=.047$; odds ratio $[\mathrm{OR}]=0.96$; $95 \%$ confidence interval $[\mathrm{CI}]=0.92-0.99)$. This study's results support the hypothesis that an increase in AFM will reduce the risk of labor complications. The pseudo- $\mathrm{R}^{2}$ was 0.0147 , which indicates that the independent variables explained $1.5 \%$ of variance in labor complications (Table 3). However, in logistic regression models of cross-sectional data, a low pseudo- $\mathrm{R}^{2}$ does not necessarily indicate that the model is not good. As it is a pseudo- $R^{2}$, its interpretation dif- 
Table 2. Distribution of Variables in the Analysis of Low Birth Weight Babies $(N=4,593)$

\begin{tabular}{|c|c|c|c|}
\hline Variables & Categories & $\mathrm{n}(\%)$ or $\mathrm{M} \pm \mathrm{SD}$ & Min-Max \\
\hline LBW babies & $\begin{array}{l}\text { No } \\
\text { Yes }\end{array}$ & $\begin{array}{c}4,187(91.2) \\
406(8.8)\end{array}$ & \\
\hline AFM & $\begin{array}{l}<20 \\
20-34 \\
\geq 35\end{array}$ & $\begin{array}{c}21.7 \pm 4.5 \\
1,639(35.7) \\
2,891(62.9) \\
63(1.4)\end{array}$ & $10-42$ \\
\hline Education (year) & & $10.4 \pm 4.3$ & $0-18$ \\
\hline Level of education & $\begin{array}{l}\text { University } \\
\text { High school } \\
\text { No school or only primary }\end{array}$ & $\begin{array}{l}1,058(23.1) \\
1,816(39.5) \\
1,719(37.4)\end{array}$ & \\
\hline Economic status & $\begin{array}{l}\text { Not poor } \\
\text { Poor }\end{array}$ & $\begin{array}{l}2,611(56.9) \\
1,982(43.1)\end{array}$ & \\
\hline Intake of iron pills & $\begin{array}{l}\geq 90 \text { Tablets } \\
<90 \text { Tablets }\end{array}$ & $\begin{array}{l}1,935(42.1) \\
2,658(57.9)\end{array}$ & \\
\hline History of pregnancy complications & $\begin{array}{l}\text { No } \\
\text { Yes }\end{array}$ & $\begin{array}{r}3,910(85.1) \\
683(14.9)\end{array}$ & \\
\hline Pregnancy status & $\begin{array}{l}\text { Planned } \\
\text { Mistimed } \\
\text { Unwanted }\end{array}$ & $\begin{array}{c}4,331(94.3) \\
231(5.0) \\
31(0.7)\end{array}$ & \\
\hline Problems accessing health services & $\begin{array}{l}\text { No } \\
\text { Yes }\end{array}$ & $\begin{array}{l}2,994(65.2) \\
1,599(34.8)\end{array}$ & \\
\hline Frequency of ANC visits & $\begin{array}{l}\text { Routine }(\geq 4) \\
\text { Not routine }(<4)\end{array}$ & $\begin{array}{c}4,195(91.3) \\
398(8.7)\end{array}$ & \\
\hline Smoker & $\begin{array}{l}\text { No } \\
\text { Yes }\end{array}$ & $\begin{array}{c}4,534(98.7) \\
59(1.3)\end{array}$ & \\
\hline
\end{tabular}

AFM, age at first marriage; ANC, antenatal care; LBW, low birth weight; Max, maximum; Min, minimum.

fers from the $\mathrm{R}^{2}$ of a linear regression model, and as long as the independent variables show significant results, the model is statistically feasible [28].

The findings of our study showed that several variables also influenced the likelihood of experiencing labor complications, including a history of pregnancy complications, poor access to health services, preparing for the delivery with one's spouse, and ANC visits. Moreover, the interaction variable between AFM and a woman's economic status positively influenced labor complications (Table 3). This interaction variable showed that women with a higher AFM and a low economic status were 1.05 times more likely to experience labor complications than women with a higher AFM and a high economic status $(p=.036$; $\mathrm{OR}=1.05 ; 95 \% \mathrm{CI}=1.00-1.10)$. In addition, women with a higher AFM and a middle economic status were 1.04 times more likely to experience labor complications than women with a higher AFM from a high economic status ( $p=.056 ; \mathrm{OR}=1.04 ; 95 \% \mathrm{CI}=1.00-1.09)$.

Mothers who had a history of pregnancy complications were 1.68 times more likely to experience complications during the delivery of their first child $(p<.001 ; \mathrm{OR}=1.68 ; 95 \% \mathrm{CI}=$ 1.35-2.09). Women who had problems accessing health services were 1.18 times more likely to experience labor complications than those who had access to health services $(p=.032$; $\mathrm{OR}=1.18$; 95\% CI=1.01-1.37). Additionally, women who did not discuss preparations for labor with their spouse or partner were 0.67 times more likely to experience labor complications $(p=.005 ; \mathrm{OR}=0.67 ; 95 \% \mathrm{CI}=0.50-0.88)$ than those who discussed preparations. Furthermore, women who received ANC fewer than four times during their pregnancy were 1.61 times more likely to experience labor complications than those who received ANC four or more times $(p=.003$; OR=1.61; $95 \% \mathrm{CI}=$ 1.17-2.19).

With regard to LBW, the model's pseudo- $\mathrm{R}^{2}$ was 0.0368 , which indicates that the independent variables can explain $3.7 \%$ of the variation in the birth of LBW babies (Table 4 ). In Table 4, model 1 shows that an increase in AFM reduces the chances of delivering LBW babies up to a certain point, when 
Table 3. Results of Binary Logistic Regression for Labor Complications

\begin{tabular}{|c|c|c|c|c|c|c|c|c|c|}
\hline \multirow{2}{*}{ Characteristics } & \multicolumn{4}{|c|}{ Model 1} & \multicolumn{5}{|c|}{ Model 2} \\
\hline & $\beta$ & $\mathrm{z}$ & OR & $p$ & $\beta$ & $\mathrm{z}$ & OR & $p$ & $95 \% \mathrm{CI}$ \\
\hline AFM & -.01 & -1.01 & 0.99 & .311 & -.04 & -1.99 & 0.96 & .047 & $0.92-0.99$ \\
\hline $\begin{array}{l}\text { AFM * economic status (ref: highest) } \\
\text { Middle } \\
\text { Lowest }\end{array}$ & & & & & $\begin{array}{l}.04 \\
.05\end{array}$ & $\begin{array}{l}1.91 \\
2.10\end{array}$ & $\begin{array}{l}1.04 \\
1.05\end{array}$ & $\begin{array}{l}.056 \\
.036\end{array}$ & $\begin{array}{l}0.99-1.09 \\
1.00-1.10\end{array}$ \\
\hline $\begin{array}{l}\text { Economic status (ref: highest) } \\
\text { Middle } \\
\text { Lowest }\end{array}$ & & & & & $\begin{array}{l}-.70 \\
-.82\end{array}$ & $\begin{array}{l}-1.25 \\
-1.49\end{array}$ & $\begin{array}{l}0.49 \\
0.44\end{array}$ & $\begin{array}{l}.210 \\
.137\end{array}$ & $\begin{array}{l}0.16-1.48 \\
0.15-1.30\end{array}$ \\
\hline Education & & & & & -.00 & -0.03 & 0.99 & .977 & 0.98-1.02 \\
\hline $\begin{array}{l}\text { History of pregnancy complications (ref: no) } \\
\text { Yes }\end{array}$ & & & & & .52 & 4.68 & 1.68 & $<.001$ & $1.35-2.09$ \\
\hline $\begin{array}{l}\text { Pregnancy status (ref: planned) } \\
\text { Mistimed } \\
\text { Unwanted }\end{array}$ & & & & & $\begin{array}{r}.19 \\
-.44\end{array}$ & $\begin{array}{r}1.10 \\
-1.02\end{array}$ & $\begin{array}{l}1.21 \\
0.64\end{array}$ & $\begin{array}{l}.273 \\
.308\end{array}$ & $\begin{array}{l}0.86-1.71 \\
0.27-1.50\end{array}$ \\
\hline $\begin{array}{l}\text { Problems accessing health services (ref: no) } \\
\text { Yes }\end{array}$ & & & & & .16 & 2.15 & 1.18 & .032 & $1.01-1.37$ \\
\hline $\begin{array}{l}\text { Knowledge of dangers and complications (ref: no) } \\
\text { Yes }\end{array}$ & & & & & .05 & 0.72 & 1.06 & .469 & $0.91-1.22$ \\
\hline $\begin{array}{l}\text { Discussion about delivery preparations (ref: yes) } \\
\text { No }\end{array}$ & & & & & -.41 & -2.80 & 0.67 & .005 & $0.50-0.88$ \\
\hline $\begin{array}{l}\text { Frequency of ANC visits (ref: routine) } \\
\text { Not routine }(<4)\end{array}$ & & & & & .48 & 3.00 & 1.61 & .003 & $1.17-2.19$ \\
\hline $\begin{array}{l}\text { Maternity assistant (ref: medical) } \\
\text { Non-medical }\end{array}$ & & & & & -.43 & -1.32 & 0.65 & .186 & $0.34-1.23$ \\
\hline & & & & & o- & 0147 & & & \\
\hline
\end{tabular}

$\mathrm{AFM}$, age at first marriage; $\mathrm{ANC}$, antenatal care; $\mathrm{CI}$, confidence interval; $\mathrm{OR}$, odds ratio; ref, reference.

the chances of delivering LBW babies increase again. The AFM and quadratic AFM variables had a statistically significant influence on the probability of LBW babies (Table 4, model 2). Thus, AFM showed a consistent, non-linear relationship with the birth of LBW babies.

The quadratic AFM variable was used to identify a reversal of the pattern between AFM and the probability of LBW babies. Indeed, the presence of a non-linear relationship indicates that the decrease in the probability of LBW babies only occurs up to a certain AFM and increases beyond that point. The turning point can be obtained by calculating the first derivative of the equation used to estimate the birth of LBW babies according to the AFM variable.

Thus, women who marry for the first time at 24.2 years old have the lowest risk of delivering LBW babies. Women who marry at a young age have a higher probability of giving birth to LBW babies, and that probability decreases until the AFM reaches 24.2 years. Beyond 24.2 years of age, the risk of giving birth to LBW babies increases. Figure 1 shows the probability distribution of LBW babies according to mothers' AFM.

Finally, the inferential results show that mothers from poor households had a $1.9 \%$ higher probability of delivering LBW babies than mothers from non-poor families $(p=.034$; marginal effect $[\mathrm{dy} / \mathrm{dx}]=0.019 ; 95 \% \mathrm{CI}=0.00-0.03)$. In addition, the probability of delivering LBW babies among women who experienced at least one type of pregnancy complication increased by $5 \%(p<.001 ;$ marginal effect $[\mathrm{dy} / \mathrm{dx}]=0.059 ; 95 \%$ $\mathrm{CI}=0.03-0.09$ ).

The results also show that the regularity of ANC visits influenced the likelihood of having LBW babies. For mothers who had irregular ANC visits (fewer than four during pregnancy), the probability of delivering LBW babies increased by $10.7 \%(p<.001$; marginal effect $[\mathrm{dy} / \mathrm{dx}]=0.107 ; 95 \% \mathrm{CI}=0.07-$ $0.15)$. 
Table 4. Results of Probit Regression for the Incidence of Low Birth Weight Babies

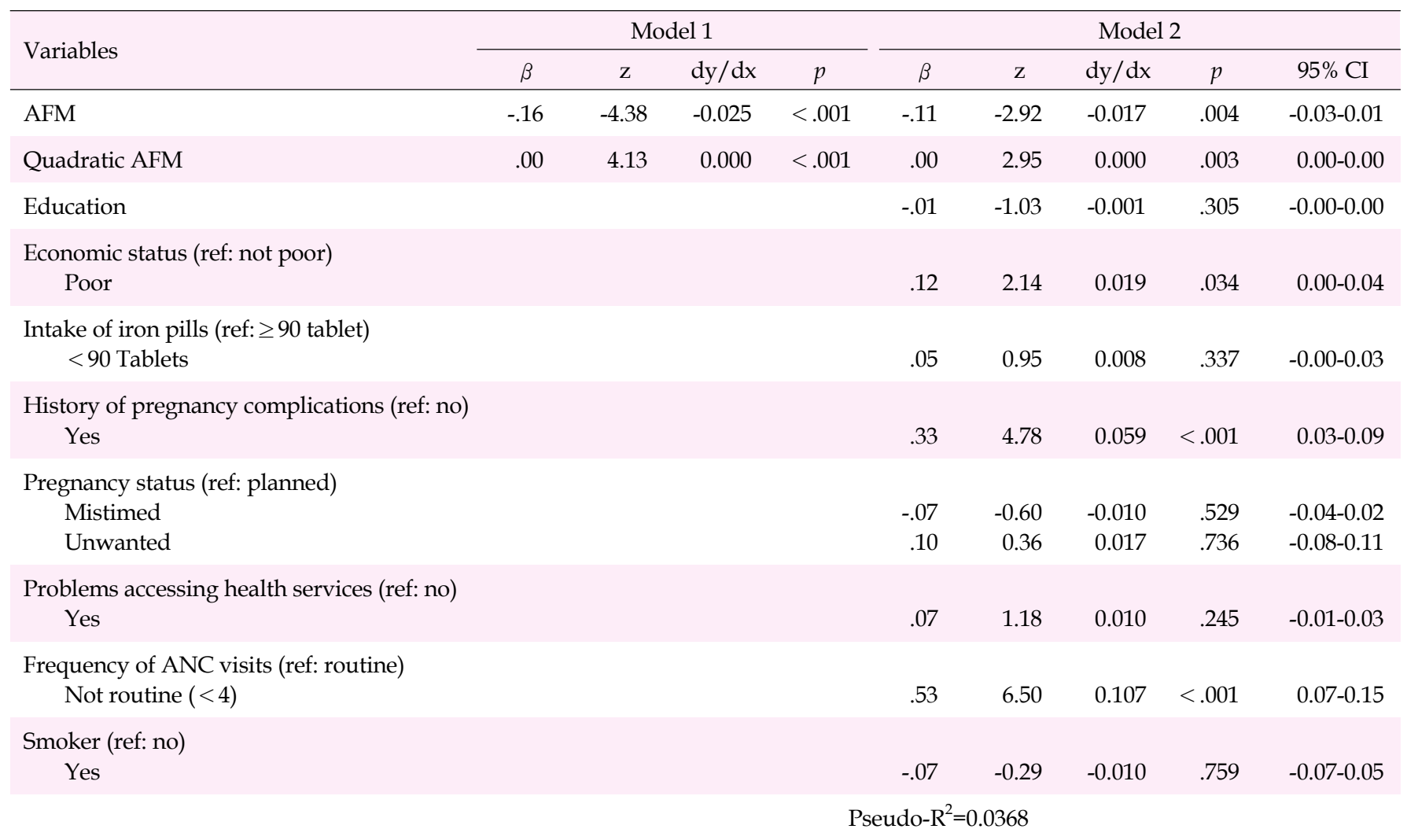

$\mathrm{AFM}$, age at first marriage; $\mathrm{ANC}$, antenatal care; $\mathrm{CI}$, confidence interval; $\mathrm{dy} / \mathrm{dx}$, marginal effect; ref, reference.

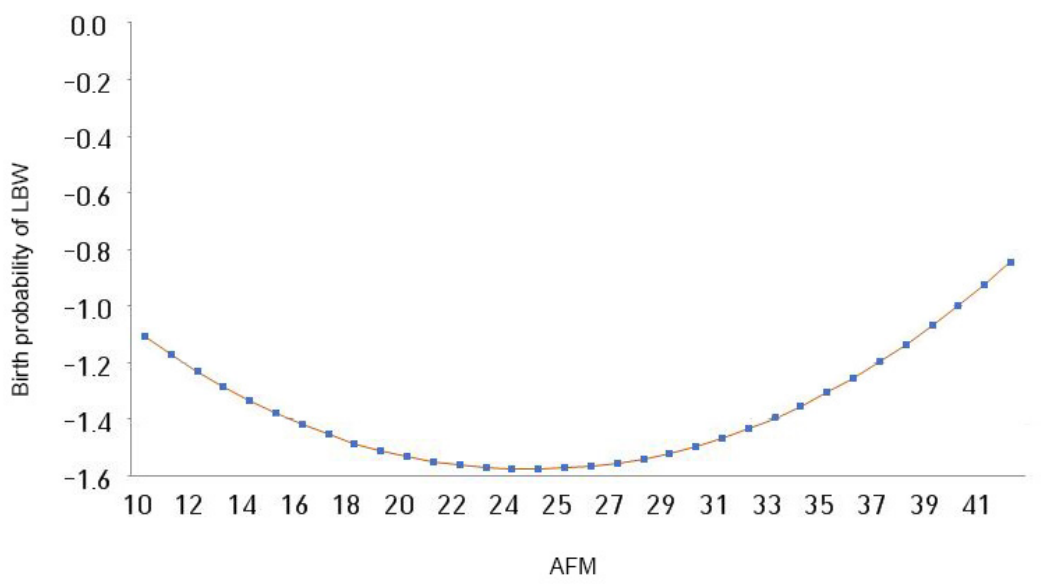

Figure 1. Birth probability pattern of low birth weight babies according to age at first marriage. AFM, age of first marriage; LBW, low birth weight.

\section{DISCUSSION}

This study found that an older AFM reduced the risk of mothers experiencing complications during the delivery of their first child. This supports McCarthy and Maine's [5] find- ings that in areas where the rate of young marriages is high, increasing the AFM reduces both fertility and the probability of labor complications. Moreover, this study confirms that the history of pregnancy complications, frequency of ANC visits, access to health services, and preparations for delivery all in- 
fluence the likelihood of labor complications. This finding is similar to those from several previous studies, which reported that pregnancy complications increased the risk of the mother experiencing labor complications [22,23]. Health problems during pregnancy can disrupt the labor process, which can ultimately lead to labor complications. Our results also support previous studies showing that routine ANC visits can reduce the likelihood of labor complications [18,23]. Hence, ANC is effective in reducing morbidity and maternal mortality by preventing, detecting, and enabling the treatment of problems during pregnancy. Furthermore, these results are consistent with previous studies concluding that access to health services influences the likelihood of labor complications [23]. Women with poor access to health services were more likely to experience labor complications than women with greater access. Additionally, women who made preparations for delivery with other people were more likely to experience labor complications. This is because women who know that their pregnancy is higher-risk are more likely to make necessary delivery preparations.

Economic differences also impacted the likelihood of labor complications. Among women with a higher AFM, those from low-income households tended to have a greater risk of experiencing labor complications than those from higher-income households. Women with an older AFM are more mature psychologically and physically, which enables them to have a deeper understanding of their responsibilities in the household and the importance of self-care. Having a low income can limit access to needed care and places additional stress on household members. Women in these households experience more pressure, which might affect their health and the health of their unborn child [29,30].

The inferential analyses found that AFM and LBW had a U-shaped relationship. As the AFM increased, the probability of having an LBW baby decreased until the age of 24 years, after which the probability of having an LBW baby gradually increased. Adolescents' reproductive health organs are still developing and may not be ready for pregnancy, which increases the probability of having an LBW baby. Pregnant adolescents must also share their nutritional intake with the fetus, which can result in insufficient nutrition for both the mother and baby. In turn, mothers may experience anemia, which can disrupt the growth of the brain cells and other organs in the fetus, negatively impacting the baby's health [1]. Conversely, previous study [19] have suggested that pregnant women who are 35 and older have a higher risk of delivering LBW babies. For women who are 35 or older, pregnancies entail health risks caused by a combination of maternal degenerative diseases and deteriorating reproductive health, which can impact the newborn's health. Thus, the results of this study support previous studies $[1,19,21]$ showing that the likelihood of delivering LBW babies increased when a mother is either too young or too old.

Nutrition also plays an important role in pregnancy. Generally, it is more difficult for poor mothers than for better-off mothers to maintain adequate maternal nutrition during pregnancy. Our results showed that poor mothers were at a higher risk of having LBW babies, supporting the findings of several past studies [20,24,25]. Furthermore, pregnancy complications and the regularity of ANC visits influenced the risk of having LBW babies. Previous studies [25] have similarly concluded that mothers with a history of pregnancy complications are at a higher risk of having LBW babies since health problems during pregnancy can disrupt the delivery process and even endanger the baby. Moreover, these results support several studies' conclusion that routine ANC visits reduce the risk of having LBW babies [20,24]. Indonesia's Ministry of Health recommends minimum of four ANC visits during pregnancy: at least one visit during both the first and second trimesters, and at least two visits during the third trimester, one of which should be accompanied by a partner/family member.

LBW is an early indicator of a child's likelihood of experiencing long-lasting malnutrition, which can interfere with a child's development into adulthood and increase the risk of low cognitive scores, obesity, and even cardiovascular disease $[10,12,13]$. In the long run, these disturbances adversely impact individuals and their families, resulting in a considerable societal burden.

\section{CONCLUSION}

An adult woman is more likely to be physiologically ready for pregnancy, which reduces the likelihood of labor complications during the delivery of her first child. However, women with a higher AFM from low- and middle-income households had a higher likelihood of labor complications than their counterparts from high-income households. This may be because, despite marrying as an adult, women from poor economic backgrounds experience heavier burdens during adolescence, which impact their health as adults, especially during pregnancy. While this study did not explore that hypothesis, it is suggested that future research consider the mental and physical condition of women who marry in adulthood.

This study also found that differences in the AFM of women affected the health of their babies. Married adolescents were more likely to have LBW babies, and an older AFM (i.e., in adulthood) reduced that likelihood. However, due to declining reproductive health conditions and higher rates of degenerative disease, women with a high AFM had an increased 
risk of delivering LBW babies. Thus, a woman's probability of birthing an LBW baby relative to her AFM shows a U-shaped curve, with higher risks found for both younger and older mothers.

Overall, this study suggests that the AFM of women influences the incidence of labor complications and LBW babies. These findings strengthen and support the Generasi Berencana program developed by BKKBN. The program was designed to prepare adolescents for family life through "marriage age maturity," encouraging women to receive an education, embark on careers, and approach marriage in a more planned manner.

A physically and mentally mature marriage will create better conditions and mitigate pregnancy complications for the long-term health of both the mother and the baby. Good economic conditions can positively impact the health of babies, but an equally valuable role in risk reduction is played by an awareness of sufficient nutritional intake during pregnancy and regular ANC visits to detect possible danger signs or complications during pregnancy and labor.

\section{ORCID}

Fajar Maulinda https://orcid.org/0000-0002-2814-268X Dwini Handayani ～https://orcid.org/0000-0002-1021-9677 Turro S. Wongkaren https://orcid.org/0000-0001-6430-8918

\section{Authors' contribution}

Conceptualization: all authors; Data curation, Formal analysis: all authors; Writing-original draft: Fajar Maulinda; Writing-review and editing: all authors; Final approval of published version: all authors.

\section{Conflict of interest}

No existing or potential conflict of interest relevant to this article was reported.

\section{Funding}

This study was funded by the Hibah Puti Shosum, Universitas Indonesia in 2020 (NKB-2507/UN2.RST/HKP.05.00/2020).

\section{Data availability}

Please contact the corresponding author for data availability.

\section{Acknowledgements}

None.

\section{REFERENCES}

1. Cinar N, Dilek M. Affects of adolescent pregnancy on health of baby. Open Journal of Pediatrics and Neonatal Care. 2017;2(1):12-23.

2. World Health Organization. Maternal mortality [Internet]. Geneva: World Health Organization; 2019 September 11 [cited 2019 December 31]. Available from:

https://www.who.int/news-room/fact-sheets/detail/maternalmortality

3. Badan Pusat Statistik. Profil penduduk Indonesia Hasil SUPAS 2015 [Internet]. Jakarta: Kepala Badan Pusat Statistik; 2016 [cited 2019 December 25]. Available from:

https://www.bps.go.id/publication/2016/11/30/63daa471092b b2cb7c1fada6/ profil-penduduk-indonesia-hasil-supas-2015.html

4. Kementerian Perencanaan Pembangunan Nasional/Bappenas. Ringkasan metadata indikator: Sustainable development goals (SDGs) Indonesia [Internet]. Jakarta: Bappenas; 2017 [cited 2019 December 25]. Available from:

http://sdgs.bappenas.go.id/wp-content/uploads/2017/09/Buku _Ringkasan_Metadata_Indikator_TPB.pdf

5. McCarthy J, Maine D. A framework for analyzing the determinants of maternal mortality. Studies in Family Planning. 1992;23(1):23-33.

6. World Health Organization. World health statistics 2019: Monitoring health for the SDGs, sustainable development goals [Internet]. Geneva: World Health Organization; 2019 [cited 2021 January 27]. Available from:

https://www.who.int/publications/i/item/world-health-statisti cs-2019-monitoring-health-for-the-sdgs-sustainable-development -goals

7. National Population and Family Palnning Board (BKKBN); Statistics Indonesia (BPS); Ministry of Health (Kemenkes); ICF. Indonesia demograhic and health survey 2017 [internet]. Jakarta, Indonesia: BKKBN, BPS, Kemenkes, ICF; 2018 [cited 2019 December 31]. Available from:

https://dhsprogram.com/publications/publication-fr342-dhs-fin al-reports.cfm?cssearch=258891_1

8. Arunda MO, Agardh A, Asamoah BO. Survival of low birthweight neonates in Uganda: Analysis of progress between 1995 and 2011. BMC Pregnancy and Childbirth. 2018;18(1):1-12

https://doi.org/10.1186/s12884-018-1831-0

9. World Health Organization. UNICEF-WHO low birthweight estimates: Level and trends 2000-2015 [Internet]. Geneva: World Health Organization; 2019 [cited 2021 January 25]. Available from: https://www.who.int/nutrition/publications/UNICEF-WHO-low birthweight-estimates-2019/en/

10. Rahman MS, Howlader T, Masud MS, Rahman ML. Association of low-birth weight with malnutrition in children under five years in Bangladesh: Do mother's education, socio-economic status, and birth interval matter? PLoS One. 2016;11(6):1-16. https://doi.org/10.1371/journal.pone.0157814 
11. Kementerian Perencanaan Pembangunan Nasional/Bappenas. Rancangan teknokratik: Rencana pembangunan jangka menengah nasional 2020-2024 [Internet]. Jakarta: Bappenas; 2019 [cited 2019 December 25]. Available from: https://www.bappenas.go.id/id/berita-dan-siaran-pers/re/

12. Upadhyay RP, Naik G, Choudhary TS, Chowdhury R, Taneja S, Bhandari N, et al. Cognitive and motor outcomes in children born low birth weight: A systematic review and meta-analysis of studies from South Asia. BMC Pediatrics. 2019;19(1):35. https://doi.org/10.1186/s12887-019-1408-8

13. Belbasis L, Savvidou MD, Kanu C, Evangelou E, Tzoulaki I. Birth weight in relation to health and disease in later life: An umbrella review of systematic reviews and meta-analyses. BMC Medicine. 2016;14(1):147. https://doi.org/10.1186/s12916-016-0692-5

14. Rita Widiadana. 'Cultural, religious norms' used as ground for early marriage: Minister. The Jakarta Post [Internet]. 2018 July 24 [cited 2021 January 28]; News: National. Available from: https://www.thejakartapost.com/news/2018/07/24/cultural-re ligious-norms-used-as-ground-for-early-marriage-minister.html

15. PUSKAPA. Pencegahan perkawinan anak: Percepatan yang tidak bisa ditunda [Internet]. Jakarta: PUSKAPA; 2020 [cited 2020 February 16 ]. Available from: https://puskapa.org/publikasi/881/

16. UNFPA. Motherhood in childhood: Facing the challenge of adolescent pregnancy [Internet]. New York: UNFPA; 2013 [cited 2020 February 21]. Available from: https://www.refworld.org/docid/52fcc7e84.html

17. Mccleary-sills J, Hanmer L, Parsons J, Klugman J. Child marriage: A critical barrier to girls' schooling and gender equality in education. The Review of Fatith and Affairs. 2015;13(3):69-88. https://doi.org/10.1080/15570274.2015.1075755

18. Hoque M. Incidence of obstetric and foetal complications during labor and delivery at a community health centre, midwives obstetric unit of Durban, South Africa. International Scholarly Research Notices. 2011;2011:259308. https://doi.org/10.5402/2011/259308

19. Moreira AIM, De Sousa PRM, Sarno F. Low birth weight and its associated factors. Einstein. 2018;16(4):eAO4251. https://doi.org/10.31744/einstein_journal/2018AO4251

20. Mahmud RA, Sultana M, Sarker AR. Distribution and determinants of low birth weight in developing countries. Journal of Preventive Medicine and Public Health. 2017;50(1):18-28. https://doi.org/10.3961/jpmph.16.087
21. Widiyanto J, Lismawati G. Maternal age and anemia are risk factors of low birth weight of newborn. Riau international nursing conference 2018: Incorporating technology and ethics in advancing nursing education and practice: 2018 November 14-15. Pekanbaru: Elsevier; 2019. p. 94-97.

https://doi.org/10.1016/j.enfcli.2018.11.010

22. Islam MA, Chowdhury RI, Chakraborty N, Bari W, Akhter HH. Factors associated with delivery complications in rural Bangladesh. The European Journal of Contraception and Reproductive Health Care. 2004:9(4):203-213. https://doi.org/10.1080/13625180400017438

23. Simarmata OS, Armagustini Y, Bisara D. Determinan kejadian komplikasi persalinan di Indonesia (analisis data sekunder survei demografi dan kesehatan Indonesia tahun 2007). Indonesian Journal of Health Ecology. 2012;11(1):11-23.

24. Dahlui M, Azahar N, Oche OM, Aziz NA. Risk factors for low birth weight in Nigeria: Evidence from the 2013 Nigeria demographic and health survey. Global Health Action. 2016;9(1).

https://doi.org/10.3402/gha.v9.28822

25. Pramono MS, Paramita A. Pola kejadian dan determinan bayi dengan berat badan lahir rendah (BBLR) di Indonesia tahun 2013 (pattern of occurrence and determinants of baby with low birth weight in Indonesia 2013). Buletin Penelitian Sistem Kesehatan. 2015:18(1): 1-10.

26. De Garbino JP; World Health Organization. Children's health and the environment: A global perspective: A resource manual for the health sector [Internet]. Geneva: World Health Organization; 2005 [cited 2021 March 7]. Available from: https://apps.who.int/iris/handle/10665/43162

27. Palamuleni ME. Socioeconomic determinants of age at first marriage in Malawi. Journal of Biosocial Science. 2011;2(7):224-235. https://doi.org/10.1017/S0021932000006477

28. Gujarati DN. Basic econometrics fourth edition. New York: Mc-Graw Hill; 2003. p. 632-633.

29. Busari AO. Prevalence and associated factors of anxiety and depression among pregnant women. Open Access Journal of Neurology and Neurosurgery. 2018;9(2):38-46. https://doi.org/10.19080/OAJNN.2018.09.555758

30. Dunkel Schetter C, Tanner L. Anxiety, depression and stress in pregnancy: Implications for mothers, children, research, and practice. Current Opinion in Psychiatry. 2012;25(2):141-148. https://doi.org/10.1097/YCO.0b013e3283503680 